This is a self-archived version of an original article. This version may differ from the original in pagination and typographic details.

Author(s): Lönnroth, Harry

Title: Suomalaista ruotsia keskiajalta nykypäivään

Year: 2020

Version: Published version

Copyright: (c) 2020 Kotikielen seura

Rights: In Copyright

Rights url: http://rightsstatements.org/page/lnC/1.0/?language=en

Please cite the original version:

Lönnroth, H. (2020). Suomalaista ruotsia keskiajalta nykypäivään. Virittäjä, 124(4), 608-611.

https://doi.org/10.23982/vir.97518 


\section{Suomalaista ruotsia keskiajalta nykypäivään}

\author{
Marika Tandefelt (toim.): Finländsk \\ svenska från medeltid till 1860. Svenskan \\ i Finland - i dag och i går III:1. Helsinki: \\ Svenska litteratursällskapet i Finland 2019. \\ 416 s. ISBN 978-951-583-456-0.
}

Marika Tandefelt (toim.): Finländsk svenska från 1860 till nutid. Svenskan i Finland - i dag och i går III:2. Helsinki: Svenska litteratursällskapet i Finland 2019. 458 s. ISBN 978-951-583-457-7.

Svenska litteratursällskapet i Finland julkaisi vuosina 2015-2019 kolmeosaisen teossarjan Svenskan i Finland - i dag och i går, jonka kuudesta niteestä yksi on monografia ja loput toimitettuja teoksia. Sarjassa tarkastellaan nimensä mukaisesti ruotsin kieltä Suomessa ennen ja nyt. Erityisinä teemoina nousevat esiin koulun ja muun yhteiskunnan kieli, proosan ja lehdistön kieli, murteet ja kaupunkikielet sekä muut puhutun kielen vaihteluun liittyvät kysymykset. Sarjan kahdessa viimeisessä niteessä näkökulma on kielihistoriallinen ja siksi erityisesti kirjoitettuun kieleen keskittyvä. ${ }^{1}$ Kirjoittajat tarkastelevat ruotsin kielen kehitystä ja muutosta Suomessa yhtäältä 140o-luvun jälkipuoliskolta vuoteen 1860 ja toisaalta vuodesta 1860 nykyaikaan, erityisesti synkronista kielentutkimusta hyödyntäen. Vuosi 1860 toimii luontevana vedenjakajana, sillä 186o-luku oli monessa suhteessa merkittävä vuosikymmen niin ruotsin kuin suomenkin näkökulmasta; esimerkkeinä mainittakoon vuoden 1863 kielireskripti ja vuoden 1866 kansakouluasetus. Termi suomenruotsi on 1900-luvun alun kielenhuollon tuote, eikä sitä siksi tavallisesti käytetä vanhemman kielihistorian osalta.

1. Teossarjan edellisiä osia ovat käsitelleet Virittäjässä Hiidenmaa (2018) ja Kuronen (2018).

\section{Keskiajalta vuoteen 1860}

Ensimmäinen kielihistoriallinen nide sisältää lyhyen johdannon lisäksi 14 lukua. Kirjoittajina on kielen- ja historiantutkijoita etupäässä Helsingistä ja Turusta. Kokoelman artikkelit muodostavat kokonaisuuden, jossa kieli ja historia nivoutuvat luontevasti yhteen. Myös lähdekriittisiä pohdintoja tuodaan riittävästi esiin, joskin joitakin käsitteitä, kuten Åbosvenska, "Turun ruotsi", olisi tosin voinut problematisoida seikkaperäisemmin. Erityisesti kielen kulttuurihistoriasta ammentavat luvut ovat mielenkiintoista luettavaa, kuten seuraavasta käy ilmi.

Jennica Thylin-Klaus ja Helena HolmCüzdan hahmottelevat kirjoituksessaan ruotsinkielisen kirjallisen kulttuurin kehityslinjoja Suomessa keskiajalta 1860-luvulle. Aihe on laaja ja haastava, mutta kirjoittajat onnistuvat tiivistämään pitkän ajallisen kehityskulun kiitettävästi. Eljas Orrman jatkaa aiheesta, josta hän on kirjoittanut jo 1990-luvulla: hän esittelee historiallisia lähteitä, joita voidaan hyödyntää tutkittaessa Suomessa käytettyä ruotsia keskiajalta 160o-luvulle. Lars Wollin puolestaan kirjoittaa pohjoismaisen filologian klassikkoaiheesta, munkki Jöns Buddesta, jota on nimitetty Suomen ensimmäiseksi nimeltä tunnetuksi kirjailijaksi. Budde vaikutti Naantalin birgittalaisluostarissa 1400-luvulla, jossa hän käänsi lähinnä uskonnollista kirjallisuutta ruotsiksi. Wollin on kirjan nordistitaustaisista kirjoittajista ainoa keskiajan kielihistorian (muinaisruotsin) tuntija; muiden kirjoittajien kiinnostus on kohdistunut uudempaan kielihistoriaan eli nuorempaan uusruotsiin ja nykyruotsiin.

Eräs teoksen mielenkiintoisimmista luvuista on Thylin-Klausin 16oo-luvun kaupunginkirjureita käsittelevä kirjoitus, jossa 
hän luo katsauksen kielihistorian kannalta keskeiseen ammattikuntaan. Kaupunginkirjurit olivat omien paikallisyhteisöjensä kielellisiä toimijoita, ja heidän toimintansa syvällinen tunteminen ja erittely ovat avainasemassa haluttaessa selvittää kirjallisen kulttuurin kehitystä Ruotsin valtakunnassa keskuksesta periferiaan.

Uudempaan kielihistoriaan eli tässä tapauksessa $1700-$ ja $1800-l u k u i h i n$ siirryttäessä esiin nousevat erityisesti yksittäisten ihmisten laatimat tekstit, jotka toimivat esimerkkeinä oman kontekstinsa tekstintuotannosta. 1700-luvun ruotsia käsitellään useassa luvussa. Charlotta af Hällström-Reijonen ja Thylin-Klaus tarkastelevat akateemista kirjoittamista 1700-luvun Turussa, siinä missä AnnMarie Ivarsin aiheena on professori ja tutkimusmatkailija Pehr Kalmin kirjeet sukulaiselleen Carl Fredrik Mennanderille. Kerstin Thelander ja Henrika Tandefelt puolestaan tarkastelevat itäuusmaalaisen aatelisneidon päiväkirjan kielellistä vaihtelua vuosina 1799-1801. 180o-luvulle tultaessa tarkasteluun nousee Johan Ludvig Runeberg, josta on kirjoitettu aiemminkin yllin kyllin. Af Hällström-Reijonen luo läpileikkauksen Runebergin "finlandismeista", joita tämä käytti kaikilla kielen tasoilla. Af Hällström-Reijonen on kirjoittanut myös luvun, jossa hän vertailee ruotsia Suomessa ja Ruotsissa diakronisesta näkökulmasta, sekä luvun ruotsin yleiskielestä Suomessa.

Kuinka paljon tällaisten aineistojen pohjalta on mahdollista sanoa 1700-luvun ruotsista, on asia erikseen, mutta yleistäminen ei aina liene tarkoituskaan. Paljon kiinnostavia arkistoja ja kielellisiä toimijoita jää joka tapauksessa vielä hyödyntämättä, semminkin kun halutaan syventää käsitystä kielihistorian moniulotteisuudesta.

Christer Kuvajan kielikontakteja ja kaksikielisyyttä 1700- ja 180o-lukujen Suomessa käsittelevä laaja luku sisältää paljon uutta tutkimustietoa kaikille kaksikielisyyden historiasta kiinnostuneille. Kuvaja tarkastelee muun muassa yksi- ja kaksikielisiä seurakuntia, ja luvun tarjoaman tiedon uutuusarvo on suuri. Tämä historiallinen kielikontakti- ja kaksikielisyysulottuvuus (tai laajemmin monikielisyys) on teema, jossa on vielä paljon tutkittavaa esimerkiksi niin sanotun Svenskfinlandin eli ruotsinkielisen rannikkoseudun ulkopuolella. Kaiken kaikkiaan on tärkeä muistaa, että ruotsia on puhuttu keskiajalla ja puhutaan nykyäänkin myös rannikkoseudun ulkopuolella.

"Viipurin ruotsia" käsittelevässä katsauksessaan Marika Tandefelt kuvaa aiemman tutkimuksen pohjalta monikielisen maineen omaavaa ja jopa hieman myyttiset mittasuhteet saanutta kieliyhteisöä. Kaisa Häkkisen luku ruotsalaisista lainasanoista suomen kielessä on tervetullut lisä kokoelmaan suomen kielen näkökulmasta; Häkkinen antaa asiantuntevan kuvan suomen ja ruotsin monessa mielessä yhteen nivoutuneesta kielihistoriasta. Teoksen luonteva päätösluku on Max Engmanin mielenkiintoinen esseistinen kirjoitus suuriruhtinaskunnan kolmesta kielestä: suomesta, ruotsista ja venäjästä.

\section{Vuodesta 1860 nykypäivään}

Teosparin jälkimmäinen, 1860-lukuun ja sitä myöhempään aikaan keskittyvä osa sisältää lyhyen johdannon lisäksi 15 lukua. Kirjoittajakunta on tällä kertaa laajentunut kirjallisuudentutkimuksen ja kasvatustieteiden edustajilla.

Teos alkaa laajalla luvulla, jossa Maren Jonasson, Thylin-Klaus ja HolmCüzdan käsittelevät tekstin demokratisoitumista. Kielenhuolto on teoksessa hyvin keskeisellä sijalla kautta linjan: ThylinKlaus kirjoittaa ruotsin kielenhuollosta Suomessa vuosina 1880-1917 ja Tandefelt suomenruotsalaisen kielenhuollon oppi-isästä Hugo Bergrothista, "kielen 
puutarhurista”. Bergrothin alun perin vuonna 1917 julkaisema Finlandssvenska on vaikuttanut merkittävästi suomenruotsalaiseen kielenhuoltoon, ja teoksen alaotsikko on aikansa lapsi: handledning till undvikande av provinsialismer $i$ tal och skrift, "johdatus provinsialismien välttämiseen puheessa ja kirjoituksessa". Thylin-Klaus käsittelee myös teatterin ja kielenhuollon kiinnostavaa suhdetta ennen vuotta 1920. Af Hällström-Reijonen piirtää suomenruotsalaisen kielenhuollon suurta linjaa Bergrothista nykyhetkeen. Koulutushistoriallisen näkökulman tuo puolestaan Sven-Erik Hansén käsitellessään kielenkehitystä ja kielenhuoltoa kansa- ja peruskoulun historiassa. Näkökulman ruotsin kieleen maamme rajojen ulkopuolella tarjoaa Ivars luvussaan suomenruotsalaisten siirtolaisten kielestä Amerikassa, Argentiinassa ja Ruotsissa.

Teoksessa on monta lukua, jotka keskittyvät yksittäisiin suomenruotsalaisiin kirjailijoihin ja heidän tuotantoonsa: Thylin-Klaus käsittelee Zacharias Topeliusta ja oikeinkirjoitusta, af HällströmReijonen sisäsuomalaista K. A. Tavaststjernaa ja oikeakielisyyttä sekä Julia Tidigs viipurilaista Jac. Ahrenbergia ja kirjallisuuden monikielisyyttä. Barbro Wiik puolestaan tarkastelee murteella kirjoitettua kirjallisuutta eritoten pohjanmaalaisen Anders J. Nygrenin tuotannossa. Clas Zilliacus keskittyy suomenruotsalaisten modernistien kieleen, ja Tandefelt esittelee suomenruotsia näyttämökielenä sadan vuoden aikana. Päätösluvut keskittyvät yhtäältä suomenruotsalaisiin puhuttelukäytänteisiin (Maria Fremer) ja toisaalta 1900-luvun kielelliseen historiaan (Tandefelt).

\section{Kieli historiassa, historia kielessä}

Kielihistoriallisen teosparin ensimmäistä osaa lukiessani huomaan kaipaavani sitä, että keskiaikaa ja sen muinaisruotsia mutta myös uuden ajan alun eli 1500- ja 160o-lukujen dynaamista kieli- ja tekstihistoriaa (vanhempaa uusruotsia) käsiteltäisiin enemmän. Viimeksi mainitusta olisi ollut saatavilla paljon aiemmin tutkimattomia aineistoja. Esimerkiksi 1500-lukua on raamatunkäännöksiä lukuun ottamatta tutkittu todella vähän niin meillä kuin Ruotsissakin verrattuna vaikkapa Buddeen, Runebergiin tai Viipuriin. Lisäksi kokoelman näkökulmille ja moniäänisyydelle olisi voinut olla eduksi, mikäli kirjoittajien joukossa olisi ollut enemmän esimerkiksi ruotsalaisia tutkijoita. Ruotsissa kielihistoriallisella tutkimuksella on kaiken kaikkiaan vankempi jalansija kuin Suomessa, ja siellä tehtävä tutkimus sivuaa usein myös Suomen kannalta relevantteja kysymyksiä. Myös digitaalinen filologia - ennen kaikkea toista tulemistaan tekevä Diplomatarium Fennicum - olisi voinut tarjota mielenkiintoisia näkökulmia käytettävissä oleviin lähdeaineistoihin.

Molemmat teokset edustavat perusvarmaa tutkimus- ja toimitustyötä, ja ne ovat monessa suhteessa tervetullut lisä kielihistoriallisen keskustelun edistämiseen. Kirjoittajat kirjoittavat sujuvasti, eikä toimitustyö juuri anna aihetta huomautuksille. Tästäkin huolimatta olisin lukijana halunnut yllättyä enemmän, sillä odotukset olivat varsin suuret. Nyt mukana on alaa seuranneelle paljon tuttua asiaa, jota monet kirjoittajat ovat käsitelleet aiemmissa yhteyksissä. Osittain ymmärrettävistä syistä kirjoista huokuu myös melko yksikielinen painotus, mikä näkyy muun muassa aihevalinnoissa ja käytetyssä kirjallisuudessa. Teosten parasta antia ovat mielestäni kulttuurihistorialliset luvut, joita leimaa sekä kielellinen että historiallinen pohdinta. Näenkin erittäin hyvänä, että kielen- ja historiantutkijat tekevät enenevää yhteistyötä, ja siitä teokset ovat konkreettinen osoitus. Siitäkin huolimatta, että ne eivät sinänsä tarjoa ruotsin kielihistoriaa tunteville erityisen paljon uusia avauksia, ne 
toimivat kuitenkin tervetulleena johdatuksena ja kokoavana katsauksena kysymyksiin, jotka osaltaan valottavat ruotsin kielen kehitystä nykyisen Suomen alueella.

HARRY LÖNNROTH etunimi.h.sukunimi@jyu.fi

Kirjoittaja on pohjoismaisten kielten professori Jyväskylän yliopistossa.

\section{Kirjallisuus}

HiidenmaA, Pirjo 2018: Suomenruotsi painettuna, koulussa ja yhteiskunnassa. - Virittäjä 122 s. 304-309. https://doi. org/10.23982/vir.68931.

Kuronen, Mikko 2018: Suomenruotsin murteista, vaihtelusta ja muuttuvasta kielimaisemasta. - Virittäjä 122 s. 297304. https://doi.org/10.23982/vir.68868.

\section{Uusia näkökulmia kielenoppimisen laajoihin mahdollisuuksiin}

Lari Kotilainen, Salla Kurhila ja Jyrki Kalliokoski (toim.): Kielenoppiminen luokan ulkopuolella. Tietolipas 262. Helsinki: Suomalaisen Kirjallisuuden Seura 2019. 360 s. ISBN 978-951-858-127-0.

Lari Kotilaisen, Salla Kurhilan ja Jyrki Kalliokosken toimittama artikkelikokoelma Kielenoppiminen luokan ulkopuolella pureutuu ajankohtaiseen ja yhteiskunnallisesti merkittävään aiheeseen. Liikkuvuuden lisääntyessä kielenoppimisen ja eri kielten osaamisen merkitys korostuu. Tämä lisää tarvetta kielenopetuksen tehostamiseen ja maahanmuuttajien työelämään ja laajemminkin yhteiskuntaan integroitumisen helpottamiseen. Säästöpaineet kuitenkin hankaloittavat esimerkiksi suomi toisena kielenä -opetusta.

Yhteiskunnallisessa keskustelussa on esitetty vaatimuksia kielenoppimiseen työpaikalla, jotta maahanmuuttajat saataisiin nopeammin työelämään. Samoin opetussuunnitelmissa puhutaan esimerkiksi "kielenopetuksen integroimisesta osaksi muuta opiskelua ja työssäoppimista" (Valtion kotouttamisohjelma vuosille 2016-2019) sekä "informaalin oppimisen kautta hankitusta taidosta" (Perusopetuksen opetussuunnitelman perusteet
2014). Teos vastaa osaltaan näihin vaatimuksiin syventämällä tietoutta luokkahuoneen ulkopuolella tapahtuvasta kielenoppimisesta ja sen monista mahdollisuuksista. Teos esittää myös mahdollisuuksia käytännön sovelluksille.

Suuri yleisö mieltänee kielenopetuksen luokkahuoneessa tapahtuvaksi opettajajohtoiseksi toiminnaksi, mutta kieltä on aina opittu myös luokan ulkopuolella: puolison ja tuttavien kanssa, työpaikalla ja vapaa-ajan aktiviteeteissa. Luokan ulkopuolisissa tilanteissa toisen kielen puhujalla voi olla monia rooleja ja tavoitteita, joista oppijuus voi nousta esiin yhtenä ulottuvuutena. Tällainen "learning in the wild" -kielenoppiminen on noussut kiinnostuksen kohteeksi maailmalla ja myös suomalaisessa kielenoppimisen tutkimuksessa (ks. esim. Strömmer 2017; Lilja \& Piirainen-Marsh 2018; Hellerman, Eskildsen, Pekarek Doehler \& Piirainen-Marsh toim. 2019). Taustalla on näkemys oppimisesta sosiaalisena toimintana, jossa kielen oppimista ei tarkastella vain yksilön kielenhallintana, vaan siihen kuuluvat myös esimerkiksi yhteisön antama tuki (sosiokulttuurinen oppimisen teoria, esim. Lave \& Wenger 1991) tai erilaiset ympäristön tarjoamat affor- 